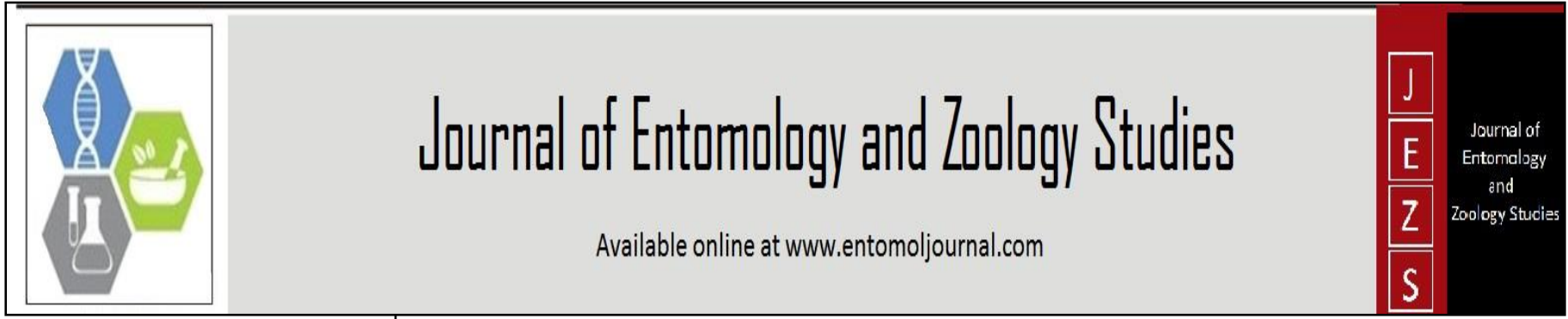

E-ISSN: 2320-7078

P-ISSN: 2349-6800

www.entomoljournal.com

JEZS 2020; 8(4): 2046-2048

(C) $2020 \mathrm{JEZS}$

Received: 12-05-2020

Accepted: 16-06-2020

Sukhwinder Singh

M.V.Sc. Scholar, Department of

Veterinary and Animal

Husbandry Extension

Education, Guru Angad Dev

Veterinary and Animal Sciences

University, Ludhiana, Punjab,

India

\section{Rajesh Kasrija}

Assistant Professor, Department

of Veterinary and Animal

Husbandry Extension

Education, Guru Angad Dev

Veterinary and Animal Sciences

University, Ludhiana, Punjab,

India

\section{Parminder Singh}

Professor, Department of

Veterinary and Animal

Husbandry Extension

Education, Guru Angad Dev

Veterinary and Animal Sciences

University, Ludhiana, Punjab,

India
Corresponding Author:

Rajesh Kasrija

Assistant Professor, Department

of Veterinary and Animal

Husbandry Extension

Education, Guru Angad Dev

Veterinary and Animal Sciences

University, Ludhiana, Punjab,

India

\section{Assessing training needs of goat farmers of Punjab for better execution of extension programmes}

\author{
Sukhwinder Singh, Rajesh Kasrija and Parminder Singh
}

DOI: $\underline{\text { https://doi.org/10.22271/j.ento.2020.v8.i4af.7427 }}$

\section{Abstract}

Present investigation was carried out to assess the training needs of goat farmers of Punjab by randomly selecting 240 goat farmers from all the six agro-climatic zones of Punjab state (40 farmers from each zone). The goat farmers were personally interviewed with the help of interview schedule at their doorstep. A total of 69 questions related to feeding, housing, breeding, health and management and miscellaneous practices were compiled. Data analysis revealed that knowledge indices about various farming practices in different agro-climatic zones of Punjab were significantly different at $P<0.05$, suggesting that knowledge about different goat farming practices varies from one agro-climatic zone to other. The ranking order for feeding, housing, breeding, health and management and miscellaneous practices for Punjab were IV, I, II, III and V. The reported training need order of Punjab is housing, breeding, health and management, feeding, miscellaneous practice, and for order I, II, III, IV and V. The present study brings light to the fact that knowledge level and training needs varies from one zone to the other. The training need assessment of goat farmer belonging to a particular area should be carried out first before organization of extension activity related to goat farming.

Keywords: Breeding, feeding, goat, housing, Punjab, training need

\section{Introduction}

The goat population in India and in Punjab is 148.88 million and 3.48 lakhs respectively ${ }^{[1]}$. Farmers and pastoralists are increasingly relying on goats as means of survival and a way of boosting their income ${ }^{[2]}$. Goat farming has huge opportunity in rural development as goat has potential for export of products, capital storage, house-hold income, employment and nutrition. It is suitable for women and could be used for rural women empowerment. For knowledge enrichment to the goat farmer, various training programmes and extension activities are carried out. But, in a training process, most important problem identified was absence of training need assessment ${ }^{[3]}$. Training need assessment of goat farmers will provide practical utility to the goat farmers and a strong feedback to the scientists, extension workers, non-governmental organizations, researchers and the animal husbandry department for planning suitable strategies and policy making for the future, so as to uplift the goat farmers. In Punjab the comprehensive study about training need assessment of goat farmers is lacking. So, present study was planned to determine knowledge index and training need of goat farmers belonging to different agro-climatic zones of Punjab.

\section{Material and Methods}

Punjab state has been divided into six different agro-climatic zones ${ }^{[4]}$ namely Sub mountain undulating zone (Zone I), Undulating plain zone (Zone II), Central plain zone (Zone III), Western plain zone (Zone IV), Western zone (Zone V) and Flood plain zone (Zone VI). From each agro-climatic zone, 40 goat farmers were randomly selected. Thus, the total number of respondents was 240 from all the six agro-climatic zones. The goat farmers were personally interviewed (to avoid the influence of other farmer's opinions) with the help of pre-structured and pre-tested interview schedule by visiting their farm at field level. The data was recorded after noting expressed opinion and after observing the things physically at goat farm. The interview schedule consist of Knowledge test, which has total 69 questions/items about feeding practices $(n=9)$, housing practices $(n=9)$ breeding practices $(n=21)$, health and 
management practices $(n=24)$ and miscellaneous practices $(n=$ 6). These questions were selected after scrutinizing relevant literature/research articles, discussion with field extension personnel and consulting concerned subject matter specialists. Goat farmers possessing knowledge about a particular practice was assigned one score and those which do not possess knowledge about that particular practice was assigned zero score. For different goat farming practices different knowledge indices, namely Knowledge index for feeding i.e. KI (f), Knowledge index for housing i.e. KI (h), Knowledge index for breeding i.e. KI (b), Knowledge index for health and management practices i.e. KI (Hm) and Knowledge index for miscellaneous practices i.e. KI (m) were calculated by dividing the total obtained score by the maximum obtainable score and multiplying the result with 100 .

\section{$\mathrm{KI}=\frac{\text { Obtained scored }}{\text { Maximum possible score }} \times 100$}

For calculation of KI (f), KI (h), KI (b), KI (Hm) and KI (m), the maximum possible score was 9, 9, 21, 24 and 6 respectively i.e. equivalent to number of items in each goat rearing practice.

The Knowledge index for goat farming was also calculated by using the following formula

$$
\mathrm{KIGF}=\mathrm{KI}(\mathrm{f})+\mathrm{KI}(\mathrm{h})+\mathrm{KI}(\mathrm{b})+\mathrm{KI}(\mathrm{H} \& \mathrm{~m})+\mathrm{KI}(\mathrm{m})
$$

The different knowledge indices of different practices were ranked in to order for different agro-climatic zones. For analysis, simple tabular techniques and Analysis of variance (ANOVA) statistical methods were employed by using SPSS version 20.0 .

\section{Results and Discussion}

It is clear from Table 1 that knowledge indices about different farming practices in different agro-climatic zones of Punjab were statistically significantly different $(P<0.05)$. It means knowledge about different farming practices varies from one agro-climatic zone to other. So, it will always be better first to access the knowledge level of farmer, then to plan extension activity in that particular area/zone. For different farming practices, maximum knowledge indices was for Zone $\mathrm{V}$, while minimum knowledge indices was for Zone VI. This indicates that goat farmers belonging to Zone $\mathrm{V}$ possess maximum knowledge among goat farmers of Punjab, while goat farmers belonging to Zone VI possess minimum knowledge.

Table 2 depicts ranking of Knowledge indices and training needs in Agro-climatic zone I, II, III and IV of Punjab. The ranking order for feeding, housing, breeding, health and management and miscellaneous practices for zone I were II, IV, I, V and III. The training need order will be reverse. So, the reported training need of zone I will be health and management, housing, miscellaneous practice, feeding and breeding for order I, II, III, IV and V. However, in adopted villages of Block Farah, Distrct Mathura, health management was the first area of training followed by housing management, other management, nutritional management and products management ${ }^{[5]}$. In Jalna district of Maharashtra, training need was reported to be 'most important' and 'not important' for 35\% and 37\% goat farmers with respect to goat care and management, for 24 and $41 \%$ with respect to goat feeding management, for 33 and $38 \%$ with respect to goat breeding management, for 45 and 30 with respect to health care and disease control management and for 34 and $36 \%$ with respect to goat marketing management ${ }^{[6] \text {. }}$

Table 3 indicates ranking of Knowledge indices and training needs in Agro-climatic zone V, VI and in Overall Punjab. The ranking order for feeding, housing, breeding, health and management and miscellaneous practices for overall Punjab were IV, I, II, III and V. The reported training need order of overall Punjab will be housing, breeding, health and management, feeding, miscellaneous practice, and for order I, II, III, IV and V. These different training need order highlighted the importance of assessment of training need before organizing extension training programme. A well established fact is that training programme based on felt training need yield better result than unorganized training programme. In Karnataka, higher level of training needs was reported in health care followed by feeding and marketing /finance ${ }^{[7]}$. However, there were multifarious need of goat farmers like feeding, breeding, housing, health care, marketing, product preparation, care and management of new born etc. But, the training need on health care and feeding aspects dominates ${ }^{[8]}$.

In Parbhani district of Maharashtra, majority of respondent perceived the importance of training in meat marketing and its export $(75 \%)$, vaccination given to goats $(62.50 \%)$, increasing twinning and triplet percentage in birth $(61.67 \%)$, stall feeding of goat $(55.00 \%)$ and fodder storage $(51.46 \%){ }^{[9]}$. In Thessaly, Greece, assessment of the small ruminants producers' training needs, highlighted the weakness of agricultural education/training programs offered to meet farmers' demand for specific knowledge. Subjects related to the health management of animal capital and issues referred to reproductive management placed high on livestock farmers' list of training priorities. Perceived training needs were influenced by factors such as farmers' age, educational level and size of livestock ${ }^{[10]}$

Table 1: Knowledge index about different farming practices in different agroclimatic zones of Punjab

\begin{tabular}{|c|c|c|c|c|c|c|c|c|}
\hline \multirow{2}{*}{ Parameter } & \multirow{2}{*}{ Farming practice } & \multicolumn{6}{|c|}{ Agro-climatic zones } & \multirow{2}{*}{$\begin{array}{l}\text { Over all } \\
(n=240)\end{array}$} \\
\hline & & I (I & II & III $(n=40)$ & IV $(n=40)$ & $\mathbf{V}(\mathrm{n}$ & VI ( & \\
\hline \multirow{5}{*}{$\begin{array}{c}\text { KI } \\
\text { (Mean } \pm \text { S.E.) }\end{array}$} & Feeding (9) & 35.28 & 33.33 & 38.61 & $45.28^{\mathrm{ab}} \pm 4.58$ & $50.83^{\mathrm{a}} \pm 4.39$ & 27.5 & $38.47 \pm 1.69$ \\
\hline & & $33.61^{\mathbf{b c}} \pm 4.24$ & $34.72^{\mathbf{b c}} \pm 4.04$ & $37.78^{\mathbf{a b}} \pm 4.22$ & $42.22^{\mathrm{ab}} \pm 4.47$ & $47.22^{\mathrm{a}} \pm 4.39$ & 23. & 1.72 \\
\hline & & $35.71^{\text {bcd }} \pm 3.85$ & $26.90^{\mathrm{d}} \pm 3.61$ & $39.76^{\mathbf{b c}} \pm 3.80$ & $43.69^{\mathrm{ab}} \pm 4.51$ & \pm 4.68 & $\mathrm{~cd}_{ \pm 2.01}$ & \\
\hline & Health and & \pm 3.62 & \pm 3.45 & 3.70 & $6 \pm 4.27$ & $48.33^{\mathrm{a}} \pm 4.75$ & $28.44^{\mathbf{b}} \pm 2.14$ & 1.59 \\
\hline & Miscellaneous (6) & $35.00^{\text {bcd }} \pm 4.08$ & $31.67^{\mathrm{cd}} \pm 3.62$ & $41.25^{\mathbf{a b c}_{ \pm}}$ & $45.83^{\mathrm{ab}} \pm 4.65$ & $52.08^{\mathrm{a}} \pm 4.82$ & $27.91^{\mathrm{d}} \pm 3.40$ & $38.96 \pm 1.7$ \\
\hline
\end{tabular}

(Values with different superscript differ significantly at $P<0.05$ ) 
Table 2: Ranking of Knowledge indices and training needs in Agro-climatic zone I, II, III and IV in Punjab

\begin{tabular}{|c|c|c|c|c|c|c|c|c|c|c|c|c|}
\hline \multirow[b]{2}{*}{$\begin{array}{l}\text { Farming } \\
\text { practice }\end{array}$} & \multicolumn{3}{|c|}{ Zone I $(n=40)$} & \multicolumn{3}{|c|}{ Zone II $(n=40)$} & \multicolumn{3}{|c|}{ Zone III $(n=40)$} & \multicolumn{3}{|c|}{ Zone IV $(n=40)$} \\
\hline & KI & $\begin{array}{c}\text { Ranking } \\
\text { of KI }\end{array}$ & $\begin{array}{c}\text { Training } \\
\text { needs } \\
\text { order }\end{array}$ & KI & $\begin{array}{c}\text { Ranking } \\
\text { of KI }\end{array}$ & $\begin{array}{c}\text { Training } \\
\text { needs } \\
\text { order } \\
\end{array}$ & KI & $\begin{array}{c}\text { Ranking } \\
\text { of KI }\end{array}$ & $\begin{array}{c}\text { Training } \\
\text { needs } \\
\text { order }\end{array}$ & KI & $\begin{array}{c}\text { Ranking } \\
\text { of KI }\end{array}$ & $\begin{array}{c}\text { Training } \\
\text { needs } \\
\text { order }\end{array}$ \\
\hline Feeding & $\begin{array}{c}35.28 \pm \\
4.32\end{array}$ & II & IV & $\begin{array}{c}33.33 \pm \\
3.60 \\
\end{array}$ & II & IV & $\begin{array}{c}38.61 \pm \\
3.92\end{array}$ & IV & II & \begin{tabular}{|c|}
$45.28 \pm$ \\
4.58
\end{tabular} & II & IV \\
\hline Housing & $\begin{array}{c}33.61 \pm \\
4.24 \\
\end{array}$ & IV & II & $\begin{array}{c}34.72^{\mathrm{bc}} \pm \\
4.04 \\
\end{array}$ & I & V & $\begin{array}{c}37.78 \pm \\
4.22 \\
\end{array}$ & V & I & $\begin{array}{c}42.22 \pm \\
4.47 \\
\end{array}$ & V & I \\
\hline Breeding & \begin{tabular}{|c|}
$35.71 \pm$ \\
3.85
\end{tabular} & I & V & $\begin{array}{c}26.90 \pm \\
3.61\end{array}$ & V & I & \begin{tabular}{|c|}
$39.76 \pm$ \\
3.80
\end{tabular} & III & III & \begin{tabular}{|c|}
$43.69 \pm$ \\
4.51
\end{tabular} & IV & II \\
\hline $\begin{array}{c}\text { Health and } \\
\text { management }\end{array}$ & $\begin{array}{c}32.71 \pm \\
3.62 \\
\end{array}$ & V & I & \begin{tabular}{|c|}
$30.94 \pm$ \\
3.45 \\
\end{tabular} & IV & II & \begin{tabular}{|l|}
$44.17 \pm$ \\
3.70 \\
\end{tabular} & I & V & $\begin{array}{c}43.96 \pm \\
4.27 \\
\end{array}$ & III & III \\
\hline Miscellaneous & $\begin{array}{c}35.00 \pm \\
4.08\end{array}$ & III & III & $\begin{array}{c}31.67 \pm \\
3.62\end{array}$ & III & III & $\begin{array}{c}41.25 \pm \\
4.42\end{array}$ & II & IV & $\begin{array}{c}45.83 \pm \\
4.65\end{array}$ & I & V \\
\hline
\end{tabular}

Table 3: Ranking of Knowledge indices and training needs in Agro-climatic zone V, VI and in Overall Punjab

\begin{tabular}{|c|c|c|c|c|c|c|c|c|c|}
\hline \multirow[b]{2}{*}{ Farming practice } & \multicolumn{3}{|c|}{ Zone V $(n=40)$} & \multicolumn{3}{|c|}{ Zone VI (n=40) } & \multicolumn{3}{|c|}{ Overall $(n=240)$} \\
\hline & KI & $\begin{array}{c}\text { Ranking } \\
\text { of KI }\end{array}$ & $\begin{array}{c}\text { Training } \\
\text { needs order }\end{array}$ & KI & $\begin{array}{c}\text { Ranking of } \\
\text { KI }\end{array}$ & $\begin{array}{c}\text { Training } \\
\text { needs order }\end{array}$ & KI & $\begin{array}{c}\text { Ranking of } \\
\text { KI }\end{array}$ & $\begin{array}{c}\text { Training needs } \\
\text { order }\end{array}$ \\
\hline Feeding & $50.83 \pm 4.39$ & III & III & $27.50 \pm 2.87$ & IV & II & $38.47 \pm 1.69$ & II & IV \\
\hline Housing & $47.22 \pm 4.39$ & $\mathrm{~V}$ & $\mathrm{I}$ & $23.61 \pm 2.95$ & $\mathrm{~V}$ & $\mathrm{I}$ & $36.53 \pm 1.72$ & $\mathrm{~V}$ & $\mathrm{I}$ \\
\hline Breeding & $52.50 \pm 4.68$ & $\mathrm{I}$ & $\mathrm{V}$ & $29.52 \pm 2.01$ & $\mathrm{I}$ & $\mathrm{V}$ & $38.01 \pm 1.65$ & IV & II \\
\hline $\begin{array}{c}\text { Health and } \\
\text { management }\end{array}$ & $48.33 \pm 4.75$ & IV & II & $28.44 \pm 2.14$ & II & IV & $38.09 \pm 1.59$ & III & III \\
\hline Miscellaneous & $52.08 \pm 4.82$ & II & IV & $27.91 \pm 3.40$ & III & III & $38.96 \pm 1.78$ & $\mathrm{I}$ & $\mathrm{V}$ \\
\hline
\end{tabular}

\section{Conclusion}

It can be concluded from foregoing that knowledge indices about various goat farming practices in different agro-climatic zones of Punjab were statistically significantly different $(P<$ $0.05)$, suggesting that knowledge about different goat farming practices varies from one agro-climatic zone to other. Also, the training need order for different zones is not same. It suggests that knowledge level and training needs of goat farmer varies from one place to another. So, same extension policy cannot be implemented on all the farmers belonging to different areas. The training need assessment of goat farmers should be given top priority before organizing extension programme for them.

\section{Acknowledgements}

Authors are thankful to the goat farmers of Punjab, who had spared their valuable times and provided information for proper execution of this study.

\section{References}

1. $20^{\text {th }}$ Livestock census in Basics Animal Husbandry Statistics 2019 Department of Animal Husbandry, Dairying and Fisheries, Ministry of Agriculture, Govt. of India, 2019 http://dadf.gov.in/sites/default/filess/BAHS\%20\%28Basi c\%20Animal\%20Husbandry\%20Statistics-2019\%29.pdf pp 91.

2. Peacock CP. Goats - A pathway out of poverty. Small Ruminant Research. 2005; 60(1):179-186.

3. Tesfaye T, Karippai RS, Tesfaye T. Farmers training programme of Ethiopian Institute of Agricultural Research: an appraisal. African Journal of Agricultural Research. 2009; 4(4):409-421.

4. Mahi, Kingra. Fundamentals of Agrometerology Kalyani Publishers, Ludhiana, 2013, 236-240.

5. Mohan B, Sagar RL, Singh K. Study on evaluation of training needs of goat farmers. Indian Journal of Small Ruminants. 2006; 12(1):21-25.
6. Tekale M, Deshmukh DS, Rathod PK, Sawant M. Training needs of goat keepers in Maharashtra. Indian Research Journal of Extension Education. 2013; 13(2):67-71.

7. Balaraju BL, Khandekar P, Chander M, Kumar DH, Rathod P. Small ruminant farmers' training needs in Karnataka as perceived by farmers and Veterinarians. The Asian Journal of Animal Science. 2014; 9(1):52-58.

8. Jena A, Mishra PKK, Ojha S. Training needs of goat farmers: An analysis. The Pharma Innovation Journal. 2018; 7(7):844-847.

9. Gaikwad SP, Bodake HD, Kalantri LB. Training needs of goat keepers. Agriculture Update. 2009; 4(1/2):82-85.

10. Lioutas ED, Tzimitra-Kalogianni I, Charatsari C. Small ruminant producers' training needs and factors discouraging participation in agricultural education/training programs. Livestock Research for Rural Development, 2010, 22, Article \#126. Retrieved July 21, 2020, from http://www.lrrd.org/lrrd22/7/liou22126.htm 